\title{
The effect of tax avoidance on cost of debt capital: Evidence from Korea ${ }^{1}$
}

\author{
H-J. Shin ${ }^{a}$ and Y-S. Woob* \\ ${ }^{a}$ Master of Business, School of Business, Ewha Womans University, Seoul, S. Korea \\ ${ }^{\mathrm{b}}$ Associate Professor, School of Business, Ewha Womans University, Seoul, S. Korea \\ *To whom all correspondence should be addressed \\ yswoo@ewha.ac.kr
}

\begin{abstract}
This study investigates the relation between tax avoidance and the cost of debt capital and analyzes the effect of the debt ratio and profitability on the relation between tax avoidance and the cost of debt. The results of our empirical analysis are as follows. First, tax avoidance is significantly positively associated with the cost of debt capital. This result shows that tax avoidance is considered as the signal of increasing information risk; thus, investors demand a higher return. Second, the debt ratio decreases the positive relation between tax avoidance and the cost of debt capital. This result indicates that the positive relation between tax avoidance and the cost of debt capital significantly decreases when the debt ratio is high. Finally, we find that the profitability of a company increases the positive relation between tax avoidance and the cost of debt capital. This result means that the cost of debt capital increases as the tax avoidance increase when the profitability of company is favorable. We find that the profitability of a company is one of the critical factors that have an effect on the relation between tax avoidance and the cost of debt capital.
\end{abstract}

\section{Introduction}

Tax avoidance generally means that a company minimizes its tax burden within the law. Sometimes tax shelters are also included in tax avoidance (Desai and Dharmapala, 2009). Because a multinational corporation's tax avoidance imposes a large loss on national economics, the U.S. and OECD began placing restrictions on this tax avoidance technique. According to the latest news from the Financial Times, Apple notified investors that the EU may impose a fine on Apple's tax avoidance from Ireland. The maximum fine may be 2.5 billion dollars. After analyzing the market response to this news, Hanlon and Slemrod (2009) suggest that the news regarding the exposure of the tax avoidance has a negative effect on the stock price. Tax avoidance has a positive effect that increases a company's after-tax cash flow; however, it has a negative effect that increases the non-tax costs such as the financial reporting cost, the agency cost and the political cost.

For a company that avoids tax cost, investors demand high returns because the quality of the accounting information is poor, and investors estimate the risk of such companies as high. Creditors also demand high returns because of the poor quality of the accounting information and the non-tax costs of tax avoidance. However, the quality of accounting information is strong when the governance structure is transparent and the company's monitoring system operates well; therefore, the cost of capital would decrease. When a company has sufficient cash to pay debt and the profitability is strong, creditors would estimate the default risk as low and demand a low return. This study investigates the relation between tax avoidance and the cost of debt capital and analyzes the effect of the debt ratio and profitability on the relation between tax avoidance and the cost of debt.

Most previous studies use the estimate suggested by Desai and Dharmapala (2006) as the proxy of tax avoidance. This estimate assumes that tax avoidance is produced by book-tax difference. However, there might be factors other than booktax difference that have an effect on tax avoidance. Therefore, this study uses the estimate suggested by Frank et al. (2009) as the proxy of tax avoidance. The estimate used in this study is a discretionary permanent difference of book-tax difference. The object of this study is to investigate how an investor judges tax avoidance from the perspective of the cost of debt capital. The implication of this study is to provide empirical evidence for the relation between tax avoidance and the cost of debt capital and to suggest evidence for the effect of company's financial characteristics on the relation between tax avoidance and the cost of debt.

This study is organized as follows. Relevant literature is discussed in the next section, and hypotheses are developed in the third section. The research model is presented in the fourth section. The fifth section outlines our empirical results and is followed by the conclusion.

\section{Literature review}

\section{Cost of debt capital}

Previous studies on the cost of capital examine the relation between the cost of capital and accruals quality. Accruals are related with future cash flow. It is necessary to make an

${ }^{1}$ This paper is revised from the master's thesis of the first author 
assumption in estimating accruals. Therefore, there might be estimation errors and subsequent correction in future accruals. Accruals quality is defined as the predictability of accruals on future cash flow. Francis et al. (2004) analyze the effect of 7 qualities of earning, i.e., accruals quality, sustainability, predictability, flexibility, relevance, timeliness, and conservatism on the cost of capital. The researchers find that accruals quality is the main factor that has the largest effect on the cost of capital. Francis et al. (2005) extend Francis et al. (2004) and investigate the relation between accruals quality and the cost of capital because they expect that the accruals quality reflects the information risk on cash flow better than other earnings qualities. The result is that a company with poor accruals quality bears a higher cost of capital than a company with strong accruals quality.

There are some previous studies on the relation between the information risk and the cost of capital. Leuz and Verrechia (2004) expect that a company with high information risk would bear a high cost of capital because investors demand a high risk premium on information risk. The result is that poor quality accounting information increases the information risk, and investors demand a high risk premium; therefore, the cost of capital also increases. . Dhaliwal et al. (2011) insist that the cost of debt capital decreases when disclosure quality is low because the reliability of investors on default risk is low.

Ahmed et al. (2002) find that conservative accounting positively affects the credit rating, which is used as a proxy of the cost of capital. The researchers insist that a company's default risk decreases as the company conducts its accounting conservatively; this makes the cost of debt capital lower.

\section{Tax avoidance}

Rego (2003) finds a low effective tax rate when a multinational corporation manages a widespread overseas business; he interprets this result as evidence of tax avoidance. Phillips (2003) finds a low effective tax rate when the compensation for a division manager is executed using an accounting-based after-tax performance index and insists that this result is evidence of tax avoidance. Accounting income is different from taxable income. Accounting income is determined by accounting standards. However, taxable income is determined by tax law. Therefore, there are differences between accounting income and taxable income that is called as book-tax differences. Book-tax differences consist of permanent differences and temporary differences. Permanent differences arise when some amounts of book income are recognized by accounting standards but this income is never recognized by tax law, or vice versa. Temporary differences arise when the period in which book income is recognized by accounting standards is different from the period in which this income is recognized by tax law. Therefore, temporary differences are removed when the unrecognized income in the previous year is recognized later. Because temporary differences are eventually removed, permanent differences would be preferred in tax avoidance. Plesko (2004) insists that ideal tax avoidance reports low taxable income and does not affect the book income and that the most ideal tax avoidance uses permanent differences rather than temporary differences. After analyzing 44 tax avoidance cases in the U.S., Graham and Tucker (2006) show that the debt ratio is low for a company that avoids taxes. Dyreng et al. (2008) suggest a cash-based effective tax rate as the long-term index of tax avoidance instead of an accrualbased effective tax rate. Chen et al. (2010) show that nonfamily firms attempt to avoid taxes more often than family firms. Lanis and Richardson (2011) show that it is unlikely for companies to avoid tax because the proportion of outside directors on the board of directors is high.

Many previous studies present the negative effects of tax avoidance on information quality and the value of a company. Desai and Dharmapala $(2006,2009)$ insist that there is a complementary relation between tax avoidance and CEOs' actions for private benefit. The researchers also state that tax avoidance has no effect on the firm value because tax avoidance is used as a means for the CEO's private benefit. Wilson (2009) insists that the book-tax difference is large for a company practicing tax avoidance; in addition, a company practicing tax avoidance tends to report financial information aggressively. Frank et al. (2009) also find that there is a positive relation between tax avoidance and aggressive financial reporting. The researchers also find that the stock price is high when a company that conducts the most aggressive financial reporting avoids taxes. Hanlon and Slemrod (2009) report that the stock price decreases when news on tax avoidance is announced. Kim et al. (2011) find that tax avoidance is positively associated with stock price crash risk. The researchers also find that this relation moderates as the institutional ownership is high, the number of analyst following the company is large, and the takeover threat is high. Chen et al. (2011) provide empirical evidence on which tax avoidance has a negative effect on the information circumstances of a company; there is a positive relation between tax avoidance and a firm's opacity. In other words, the default risk of a company increases.

\section{Hypotheses development}

If the firm's value decreases from tax avoidance, it may be possible for a creditor to not receive the principal and interest payments. Thus, a creditor would demand a higher cost of capital. According to a previous study (Chen et al. 2011), the accounting transparency and the quality of financial reporting is impaired when the tendency of tax avoidance is high. Hence, if a company that attempts tax avoidance earns an unfavorable evaluation, a creditor would demand a higher return. Therefore, it is expected that there is a positive relation between tax avoidance and the cost of debt capital. The hypothesis is developed as follows.

Hypothesis 1: Ceteris paribus, tax avoidance is significantly positively associated with the cost of debt capital.

The interest expense is deduced from the taxable income. Because of the tax shield provided by debt, the taxable income decreases as the interest expense increases. Therefore, 
it is expected that a company that has much debt does not tend to avoid tax because of debt's tax shield. High leverage also makes company monitoring by creditors efficient; thus, tax avoidance would decrease. Decreasing the tax avoidance would lower the cost of debt capital. When the debt ratio is high, the default risk would increase, and creditors would demand higher interest rates. Because there are two conflicting effects of tax avoidance on the interest rate, the second hypothesis is developed as a null type.

Hypothesis 2: Ceteris paribus, the debt ratio has no effect on the relation between tax avoidance and the cost of debt capital.

In many cases, the taxable income increases when the accounting income increase, because most of book-tax differences are accounting expenses but not deductible for tax. In book-tax differences, accounting revenues but not subject to taxation are rare. Therefore, the taxable income would more likely increase when the accounting income increases. Thus, the CEO would more likely be tempted to avoid tax when the profitability is high. If a firm avoids tax, the firm's value would be impaired and the principal and interest payments would not be made. However, when the profitability of company is high, there would be a greater possibility for creditors to collect principal and interest than when there is low profitability. Therefore, when the profitability of company is high, the relation between tax avoidance and the cost of debt capital would be weakened. Therefore, we establish the following hypothesis.

Hypothesis 3: Ceteris paribus, the relation between tax avoidance and the cost of debt capital would be weakened when the profitability of the company is high.

\section{Research design}

\section{The measure of tax avoidance}

Many previous studies use the measure suggested by Desai and Dharmapala (2006), which estimates tax avoidance using total amount of book-tax differences. However, the measure of Desai and Dharmapala (2006) may include factors other than tax avoidance that affect the book-tax difference. Therefore, it is necessary to separately investigate a temporary tax deferral and a permanent tax avoidance. This study adopts the method of Frank et al. (2009) to estimate tax avoidance and uses the discretionary permanent book-tax difference as a measure of tax avoidance. The model of Frank et al. (2009) to estimate tax avoidance is as follows.

$$
\text { PERMDIFF }_{t}=\beta_{0}+\beta_{1} I N T A N G_{t}+\beta_{2} \operatorname{CSTE}_{t}+\varepsilon_{t}
$$

where

PERMDIFF: permanent book-tax difference in year $\mathrm{t}$ divided by total assets at the beginning of year $\mathrm{t}$; INTANG $t_{t}$ : goodwill and other intangible assets at the end of year $\mathrm{t}$ divided by total assets at the beginning of year $\mathrm{t}$; CSTE $_{t}$ : corporate income tax expense in year $\mathrm{t}$ divided by total assets at the beginning of year $t$.

In model (1), the residual represents tax avoidance. To estimate the residual of model (1), the book-tax difference must be measured first. According to Frank et al. (2009), the temporary and permanent book-tax difference can be divided with this model.

$B_{t}=$ TEMPDIFF $_{t}+$ PERMDIFF $_{t}$

where

$B T D_{t}$ : book-tax difference (book income - taxable income) at the end of year $\mathrm{t}$;

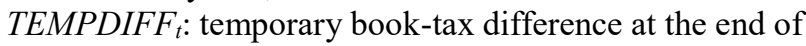
year $\mathrm{t}$;

PERMDIFF: permanent book-tax difference at the end of year $\mathrm{t}$;

The temporary book-tax difference is estimated using the difference between a corporate income tax expense and a corporate tax payment. The estimation of a corporate tax payment is as follows.

$$
C T P_{t}=C T E_{t}+\left(D T A_{t}-D T A_{t-1}\right)-\left(D T L_{t}-D T L_{t-1}\right)
$$

where

$\operatorname{CTP}_{t}$ : corporate tax payment in year $\mathrm{t}$;

$C T E_{t}$ : corporate income tax expense in year $\mathrm{t}$;

$D T A_{t(\text { or } t-1)}$ : deferred tax assets at the end of year $\mathrm{t}($ or $\mathrm{t}-1)$; $D T L_{t(\text { or } t-1)}$ : deferred tax liability at the end of year $\mathrm{t}($ or $\mathrm{t}-$ 1).

Taxable income is calculated by dividing the corporate tax payment by the corporate income tax rate.

\section{The estimate of cost of debt}

The cost of debt capital is an expense that a company bears to use debt. This cost is estimated using the total financial expense divided by the average liabilities that bear interest (Pittman and Fortin, 2004). Liabilities that bear interest include short-term borrowings, the current portion of longterm obligations, bonds, long-term borrowings and capital lease liabilities.

$C O D_{t}=T F E_{t} \div A L B I_{t}$

where

$C O D_{t}$ : cost of debt capital in year $\mathrm{t}$;

$T F E_{t}$ : total financial expense (interest expense + losses on retirement of bonds - gains on retirement of bond + capitalized interest) in year $\mathrm{t}$;

$A L B I_{t}$ : average liabilities that bear interest expense in year t. 


\section{Research Model}

The model that is used to investigate Hypothesis 1 is as follows.

$$
\begin{aligned}
& C O D_{t}=\beta_{0}+\beta_{I} T A V_{t}+\beta_{2} S_{Z I Z E_{t}}+\beta_{3} L E V_{t}+\beta_{4} R O A_{t} \\
& +\beta_{5} \mathrm{CFO}_{t}+\beta_{6} \mathrm{BETA}_{t}+\beta_{7} \mathrm{VOL}_{t}+\sum I D+ \\
& \sum Y D+\varepsilon_{t}
\end{aligned}
$$

where

$C O D_{t}$ : cost of debt capital in year t;

$T A V_{t}$ : measure of tax avoidance in year $\mathrm{t}$;

$S I Z E_{t}$ : natural logarithm of total assets at the end of year $\mathrm{t}$

$L E V_{t}$ : debt ratio at the end of year $\mathrm{t}$;

$R O A_{t}$ : return on assets in year $\mathrm{t}$;

$\mathrm{CFO}_{t}$ : proportion of operating cash flow on total assets of year $\mathrm{t}$;

$B E T A_{t}:$ systematic risk of stock return in year $\mathrm{t}$;

$V O L_{t}$ : volatility of stock return in year $\mathrm{t}$;

$I D$ : industry dummy;

$Y D$ : year dummy

Because the accounting transparency and the accounting earnings quality are poor in a company that avoids tax, investors will demand a higher return. Therefore, the coefficient $\beta_{l}$, which represents the relation between tax avoidance and the cost of debt capital, would be significantly positive. The following model is used to investigate Hypothesis 2.

$$
\begin{aligned}
C O D_{t}= & \beta_{0}+\beta_{1} T A V_{t}+\beta_{2} L E V D_{t}+\beta_{3} T A V_{t} \times L_{E V D}+ \\
& \beta_{4} S_{Z} E_{t}+\beta_{5} R O A_{t}+\beta_{6} C F O_{t}+\beta_{7} \text { BETA }_{t}+\beta_{8} \\
& V O L_{t}+\sum I D+\sum Y D+\varepsilon_{t}
\end{aligned}
$$

where

$C O D_{t}:$ cost of debt capital in year t;

$T A V_{t}$ : measure of tax avoidance in year $\mathrm{t}$;

$L E V D_{t}: 1$ is the larger debt ratio than the first quartile in each industry, otherwise 0 ;

$S I Z E_{t}$ : natural logarithm of total assets at the end of year $\mathrm{t}$

$R O A_{t}:$ return on assets in year $\mathrm{t}$;

$C F O_{t}$ : proportion of operating cash flow on total assets of year $\mathrm{t}$;

$B E T A_{t}$ : systematic risk of stock return in year $\mathrm{t}$;

$V O L_{t}$ : volatility of stock return in year $\mathrm{t}$;

$I D$ : industry dummy;

$Y D$ : year dummy.

In model (6), the main independent variable is $T A V_{t} \times L E V D_{t}$. It is expected that the relation between tax avoidance and the cost of debt capital is weakened as the debt ratio increases. Thus, the coefficient $\beta_{3}$ would be significantly negative. The model that is used to investigate Hypothesis 3 is as follows.
$C O D_{t}$

$$
\begin{aligned}
= & \beta_{0}+\beta_{1} T A V_{t}+\beta_{2} R O A D_{t}+\beta_{3} T A V_{t} \times R O A D_{t}+ \\
& \beta_{4} S_{Z} E_{t}+\beta_{5} L E V_{t}+\beta_{6} C F O_{t}+\beta_{7} B_{E T A_{t}}+\beta_{8} \\
& V O L_{t}+\sum I D+\sum Y D+\varepsilon_{t}
\end{aligned}
$$

where

$C O D_{t}$ : cost of debt capital in year $\mathrm{t}$;

$T A V_{t}$ : measure of tax avoidance in year $\mathrm{t}$;

$R O A D_{t}: 1$ if a return on assets is larger than the first quartile in each industry, otherwise 0;

$S I Z E_{t}$ : natural logarithm of total assets at the end of year $\mathrm{t}$;

$L E V_{t}$ : debt ratio at the end of year $\mathrm{t}$;

$C F O_{t}$ : proportion of operating cash flow on total assets of year $\mathrm{t}$;

$B E T A_{t}$ : systematic risk of stock return in year $\mathrm{t}$;

$V O L_{t}$ : volatility of stock return in year $\mathrm{t}$;

ID: industry dummy;

$Y D$ : year dummy.

The main independent variable in this model is $T A V_{t} \times R O A D_{t}$. In Hypothesis 3, it is expected that the relation between tax avoidance and the cost of debt capital is weakened as the profitability of company increases. Therefore, the coefficient $\beta_{3}$ would be significantly negative.

Other independent variables are used as control variables, which are presented in previous studies that have an effect on the cost of debt capital. Sengupta (1998) finds that the market risk decreases and the cost of debt capital decreases as the size of the company increases. To control the effect of the company size on the cost of debt capital, the natural logarithm of total assets is included in the model as a control variable. Because creditors estimate risk high when the debt ratio is high, the cost of debt capital would increase as the debt ratio increases (Francis et al., 2005). Therefore, it is expected that there is a positive relation between the debt ratio and the cost of debt capital (Pittman and Fortin, 2004). The return on assets represents the profitability of a company; ROA is expected to have a negative association with the cost of debt capital. The proportion of operating cash flow to total assets also represents the profitability of a company; a CFO is also expected to have a negative association with the cost of debt capital (Pittman and Fortin, 2004). The systematic risk of the stock return is beta, which is estimated by the 1 factor market model using the monthly return during the 60 months before year t. According to the Capital Asset Pricing Model (CAPM), the systematic risk of the stock return is positively associated with the cost of capital (Francis et al., 2004). The volatility of the stock return is the volatility of the residual, which is estimated by the 1 factor market model using the monthly return during the 60 months before year t. Because uncertainty is high and the volatility of the stock return is high, investors would demand a high risk premium (Anderson et $a l ., 2004)$. An industry dummy and a year dummy are also included in our model to control the effects of specific industry and economic fluctuations. 


\section{Sample selection}

Our sample consists of companies that are listed in the Korea Exchange (KRX) from 2001 to 2013. We eliminated firm-years with a fiscal year-end other than December 31 and those operating in the financial industry. Firm-years that suffer capital impairment and negative taxable income are also eliminated. Only those firm-years whose financial data are available in TS2000 and the FN DataGuide database are included in our sample. The final sample consists of 4,050 firm-years.

\section{Empirical results}

\section{Descriptive statistics}

Table 1 shows the descriptive statistics for the dependent, independent and control variables used in this study.

The mean of $C O D$ is 0.0447 , which shows that the average annual interest rate of the sample companies is approximately $4 \%$ during the sample period. The mean and median of TAV is -0.0139 and -0.0063 , respectively. The difference between the mean and median of $T A V$ is not large. The mean of SIZE is 26.6390, which shows that the average total assets of sample companies is approximately 370.8 billion Korean Won. The mean of $L E V$ is 0.9497 , which shows that the average debt ratio of the sample companies is approximately $95 \%$ during the sample period. The mean of $R O A$ is 0.0444 , which shows that the average return on assets of the sample companies is approximately $4 \%$ during the sample period. The mean of $C F O$ is 0.0575 , which shows that the average operating cash flow of sample companies is approximately $6 \%$ of total assets during the sample period.

\section{Table 1: Descriptive statistics}

\begin{tabular}{c|ccccc}
\hline & Mean & St. Dev. & $1^{\text {st }}$ Quartile & Median & $\begin{array}{c}3^{\text {rd }} \\
\text { Quartile }\end{array}$ \\
\hline COD $t$ & 0.0447 & 0.0298 & 0.0296 & 0.0423 & 0.0554 \\
$T A V_{t}$ & -0.0139 & 0.0602 & -0.0365 & -0.0063 & 0.0187 \\
$S I Z E_{t}$ & 26.6390 & 1.4383 & 25.6147 & 25.3769 & 27.4122 \\
$L E V_{t}$ & 0.9497 & 0.8242 & 0.4002 & 0.7489 & 1.2612 \\
$R O A_{t}$ & 0.0444 & 0.0560 & 0.0175 & 0.0425 & 0.0730 \\
$C F O_{t}$ & 0.0575 & 0.0724 & 0.0151 & 0.0552 & 0.0997 \\
BETA $_{t}$ & 0.7119 & 0.3558 & 0.4531 & 0.6906 & 0.9419 \\
VOL $_{t}$ & 0.4483 & 0.1550 & 0.3380 & 0.4256 & 0.5389 \\
\hline
\end{tabular}

Variable Definitions

$C O D_{t}$ : cost of debt capital in year $\mathrm{t}$;

$T A V_{t}$ : measure of tax avoidance in year $\mathrm{t}$;

$S I Z E_{t}:$ natural logarithm of total asset at the end of year $\mathrm{t}$;

$L E V_{t}$ : debt ratio at the end of year $\mathrm{t}$;

$R O A_{t}$ : return on asset in year $\mathrm{t}$;

$C F O_{t}$ : proportion of operating cash flow on total asset of year $\mathrm{t}$;

BETA $_{t}$ : systematic risk of stock return in year $\mathrm{t}$;

$V O L_{t}$ : volatility of stock return in year $\mathrm{t}$;

\section{Correlation analysis}

Table 2 presents the Pearson's correlation coefficients for the dependent, independent and control variables used in this study.

Table 2: Correlation coefficients

\begin{tabular}{|c|c|c|c|c|c|c|c|}
\hline & $T A V_{t}$ & $S I Z E_{t}$ & $L E V_{t}$ & $R O A_{t}$ & $C F O_{t}$ & BETA $_{t}$ & $V O L_{t}$ \\
\hline$C O D_{t}$ & $\begin{array}{r}-0.0369 \\
(0.0190)\end{array}$ & $\begin{array}{r}-0.0052 \\
(0.7387)\end{array}$ & $\begin{array}{r}0.2757 \\
(<.0001)\end{array}$ & $\begin{array}{r}-0.2112 \\
(<.0001)\end{array}$ & $\begin{array}{l}-0.0655 \\
(<.0001)\end{array}$ & $\begin{array}{r}0.0755 \\
(<.0001)\end{array}$ & $\begin{array}{r}0.2363 \\
(<.0001)\end{array}$ \\
\hline$T A V_{t}$ & & $\begin{array}{r}0.0351 \\
(0.0254) \\
\end{array}$ & $\begin{array}{r}-0.1051 \\
(<.0001) \\
\end{array}$ & $\begin{array}{r}0.3989 \\
(<.0001) \\
\end{array}$ & $\begin{array}{r}0.1661 \\
(<.0001) \\
\end{array}$ & $\begin{array}{r}-0.0189 \\
(0.2287) \\
\end{array}$ & $\begin{array}{r}-0.1188 \\
(<.0001) \\
\end{array}$ \\
\hline$S I Z E_{t}$ & & & $\begin{array}{r}0.1962 \\
(<.0001)\end{array}$ & $\begin{array}{r}0.0530 \\
(0.0007)\end{array}$ & $\begin{array}{r}0.0737 \\
(<.0001) \\
\end{array}$ & $\begin{array}{r}0.3482 \\
(<.0001)\end{array}$ & $\begin{array}{r}-0.1670 \\
(<.0001)\end{array}$ \\
\hline$L E V_{t}$ & & & & $\begin{array}{r}-0.3912 \\
(<.0001)\end{array}$ & $\begin{array}{r}-0.1594 \\
(<.0001)\end{array}$ & $\begin{array}{r}0.1786 \\
(<.0001)\end{array}$ & $\begin{array}{r}0.2464 \\
(<.0001)\end{array}$ \\
\hline$R O A_{t}$ & & & & & $\begin{array}{r}0.4310 \\
(<.0001)\end{array}$ & $\begin{array}{r}0.0000 \\
(0.9991)\end{array}$ & $\begin{array}{r}-0.1083 \\
(<.0001)\end{array}$ \\
\hline$C F O_{t}$ & & & & & & $\begin{array}{r}0.0008 \\
(0.9576)\end{array}$ & $\begin{array}{r}-0.0809 \\
(<.0001)\end{array}$ \\
\hline$B E T A_{t}$ & & & & & & & $\begin{array}{r}0.4702 \\
(<.0001)\end{array}$ \\
\hline
\end{tabular}

The value in parenthesis is p-value. See Model (5) for definitions of the variables used

Similar to previous studies, $C O D$ is significantly positively related with $L E V, B E T A$ and $V O L$. COD is significantly negatively related with $R O A, C F O$ and $S I Z E$. Contrary to our expectation, $C O D$ is significantly negatively related with $T A V$. However, this result is the result of univariate analysis that solely considers the relation between $C O D$ and $T A V$. It is possible that the result is changed when other variables are included in the analysis. Thus, multivariate regression analysis will be conducted.

\section{Regression results}

Table 4 presents the results of the multivariate regression analysis conducted to test Hypotheses 1, 2 and 3. In Hypothesis 1, the dependent variable is the cost of debt capital $(C O D)$, and the main independent variable is the estimate of tax avoidance (TAV), which is estimated based on Frank et al. (2009)'s research methodology. The empirical result shows that $T A V$ is significantly positively associated with $C O D$. This result suggests that a company that has a 
strong tendency to avoid tax bears a high cost of debt capital. Therefore, Hypothesis 1 is supported. We interpret this result as follows. Aggressive tax avoidance impairs a company's accounting transparency and increases the uncertainty of participants' expectations regarding future earnings in the capital markets. When a company's accounting transparency is impaired, the information asymmetry among the interested parties increases. This situation impairs the efficiency of the capital market and increases the uncertainty of the investment. Consequently, the cost of capital increases. Participants in capital markets underestimate the reliability of the accounting information for a company that attempts to avoid taxes. Therefore, because the information risk recognized by participants in capital market is increased and participants demand a high return, the cost of debt capital increases.

According to the result of multivariate regression analysis conducted to test Hypothesis 2, the interaction variable of tax avoidance and the debt ratio dummy $(T A V \times L E V D)$ is significantly negatively associated with the cost of debt capital $(C O D)$. This result suggests that creditors do not negatively evaluate tax avoidance for a company with a high debt ratio. Thus, Hypothesis 2 is supported. Tax avoidance is separated into illegal tax evasion and legal tax reduction. When the debt ratio is high, a company's creditors would be more concerned that the debt ratio is low, and they would monitor business decisions. Creditors would be concerned with illegal tax evasion because it would bear a non-tax cost such as reputation impairment and additional tax payment. These non-tax costs may impair the profitability of the company; thus, creditors would be less likely to collect the interest and principal on the due date. Therefore, the company is unlikely to illegally evade taxes when it has a high debt ratio because of creditors' monitoring. When the debt ratio is high, creditors would consider tax avoidance as a legal tax reduction despite high tax avoidance because the company is unlikely to illegally evade taxes when the debt ratio is high. Thus, creditors would not respond negatively to tax avoidance when the debt ratio is high.

The result of testing Hypothesis 3 is as follows. The interaction variable of tax avoidance and the return on assets dummy $(T A V \times R O A D)$ is significantly positively associated with the cost of debt capital $(C O D)$. This result suggests that creditors respond positively to tax avoidance when the return on assets is high; this evidence is contrary to our expectations. If a company's revenue is sufficient to pay interest and principal, creditors would expect that they can collect interest and principal without risk. If the revenue exceeds a sufficient level to pay interest and principal, creditors would not be concerned because there is no impact on the collection of interest and principal. Therefore, tax avoidance would be a potential risk that increases the non-tax cost when revenue exceeds a sufficient level to pay the interest and principal. However, when the profitability of company is low, tax avoidance would be regarded positively because creditors are preferentially concerned with the possibility of collecting the interest and principal. Therefore, the cost of debt capital would decrease when a company with low profitability avoids taxes because creditors regard it as ensuring the collection of interest and principal.

\section{Table 3: Regression results}

\begin{tabular}{|c|c|c|c|c|c|c|}
\hline \multirow[b]{2}{*}{ Variables } & \multicolumn{2}{|c|}{ Hypothesis 1} & \multicolumn{2}{|c|}{ Hypothesis 2} & \multicolumn{2}{|c|}{ Hypothesis 3} \\
\hline & $\begin{array}{c}\text { Estimated } \\
\text { Coefficients }\end{array}$ & t-stat & $\begin{array}{c}\text { Estimated } \\
\text { Coefficients }\end{array}$ & t-stat & $\begin{array}{c}\text { Estimated } \\
\text { Coefficients }\end{array}$ & t-stat \\
\hline Intercept & -0.008 & -0.72 & -0.016 & -1.48 & -0.004 & -0.38 \\
\hline$T A V_{t}$ & 0.023 & $2.73^{* * *}$ & 0.041 & $4.27^{* * *}$ & -0.033 & $-3.55^{* * *}$ \\
\hline$L E V D_{t}$ & & & 0.005 & $4.95^{* * *}$ & & \\
\hline$T A V_{t} \times L E V D_{t}$ & & & -0.051 & $-3.31^{* * *}$ & & \\
\hline$R O A D_{t}$ & & & & & -0.001 & -0.96 \\
\hline$T A V_{t} \times R O A D_{t}$ & & & & & 0.077 & $4.76^{* * *}$ \\
\hline$S I Z E_{t}$ & 0.001 & $2.45^{* *}$ & 0.001 & $3.45^{* * *}$ & 0.001 & $1.80^{*}$ \\
\hline$L E V_{t}$ & 0.006 & $8.94^{* * *}$ & & & 0.007 & $12.26^{* * *}$ \\
\hline$R O A_{t}$ & -0.096 & $-9.37^{* * *}$ & -0.111 & $-11.21^{* * *}$ & & \\
\hline$C F O_{t}$ & 0.006 & 0.86 & 0.007 & 1.00 & -0.014 & $-2.17^{* *}$ \\
\hline BETA $_{t}$ & -0.003 & $-1.84^{*}$ & -0.004 & $-2.24^{* *}$ & -0.003 & $-1.99^{* *}$ \\
\hline$V O L_{t}$ & 0.022 & $5.56^{* * *}$ & 0.027 & $6.73^{* * *}$ & 0.021 & $5.21^{* * *}$ \\
\hline$I D$ & & & Included & & & \\
\hline$Y D$ & & & Included & & & \\
\hline Observations & 4,050 & & 4,050 & & 4,050 & \\
\hline Adj $R^{2}$ & 0.2025 & & 0.1960 & & 0.1896 & \\
\hline F-value & $28.80^{* * *}$ & & $26.97 * * *$ & & $25.93 * * *$ & \\
\hline
\end{tabular}




\section{Conclusion}

This study investigates the relation between tax avoidance and cost of debt capital and analyzes the effect of company's financial characteristics on the relation between tax avoidance and cost of debt capital. Tax avoidance is estimated using the method suggested by Frank et al. (2009), and the cost of debt capital is estimated using the total financial expenses divided by the average debt that bears interest, as suggested by Pittman and Fortin (2004).

The results of the empirical analysis are as follows. First, tax avoidance is significantly positively associated with the cost of debt capital. This result shows that tax avoidance is considered as the signal of increasing information risk; thus, investors demand a higher return. Second, the debt ratio decreases the positive relation between tax avoidance and the cost of debt capital. This result indicates that the positive relation between tax avoidance and the cost of debt capital significantly decreases when the debt ratio is high. Finally, we find that the profitability of a company increases the positive relation between tax avoidance and the cost of debt capital. This result means that the cost of debt capital increases as the tax avoidance increase when the profitability of company is favorable. Because the profitability of company is not related to the interest and principal collected by creditors when the profitability achieves a certain level, creditors respond negatively to tax avoidance, which bears non-tax costs such as reputation impairment and additional tax payments. Although this result does not support Hypothesis 3 , we find that the profitability of a company is one of the critical factors that have an effect on the relation between tax avoidance and the cost of debt capital.

Previous studies on tax avoidance adopt the method presented by Desai and Dharmapala (2006) and estimate the tax avoidance of the unexplainable portion in the book-tax difference using total accrual. However, there is a problem; the determinants of the book-tax difference may include factors other than tax avoidance. Thus, it is necessary to separate a temporary tax deferral and a permanent tax avoidance. This study uses the method presented by Frank et al. (2009) to estimate the tax avoidance using the discretionary permanent difference of a book-tax difference. This study is the first study that investigates whether the financial condition of the company has an effect on the relation between tax avoidance and the cost of debt capital.

\section{References}

Ahmed, A., Billings, B., Morton, R. \& Harris, M. 2002. 'The role of accounting conservatism in mitigating bondholder-shareholder conflicts over dividend policy and in reducing debt costs', The Accounting Review, 77(4): 867-890.

Anderson, R., Manci, S. \& Reeb, D. 2004. 'Board charateristics, accounting report integrity, and the cost of debt', Journal of Accounting and Economics, 37: 315-342.

Chen, S., Chen, X., Cheng, Q. \& Shevlin, T. 2010. 'Are family firms more tax aggressive than non-family firm?', Journal of Financial Economics, 95(1): 41-61.
Chen, Y., Huang, S., Pereira, R. \& Wang, J. 2011. Corporate tax avoidance and firm opacity, Working Paper, University of Missouri.

Desai, M.A. \& Dharmapala, D. 2006. 'Corporate tax avoidance and high powered incentives', Journal of Financial Economics, 79(1): 145-179.

Desai, M.A. \& Dharmapala, D. 2009. 'Corporate tax avoidance and firm value', The Review of Economics and Statistics, 91(3): 537-546.

Dhaliwal, D., Hogan, C., Trezevant, R. \& Wilkins, M. 2011. 'Internal control disclosures, monitoring, and the cost of debt', The Accounting Review, 86(4): 1131-1156.

Dyreng, S.D., Hanlon, M. \& Maydew, E.L. 2008. 'Long-run corporate tax avoidance', The Accounting Review, 83(1): 61-82.

Francis, J., LaFond, R., Olsson, P. \& Shipper, K. 2004. 'Cost of equity and earnings attributes', The Accounting Review, 79(4): 9671010.

Francis, J., LaFond, R., Olsson, P. \& Shipper, K. 2005. 'The market pricing of accruals quality', Journal of Accounting and Economics, 39: 295-327.

Frank, M.M., Lynch, L.J. \& Rego S.O. 2009. 'Tax reporting aggressiveness and its relation to aggressive financial reporting', The Accounting Review, 84(2): 467-496.

Graham, J.R. \& Tucker, A.L. 2006. 'Tax shelters and corporate debt policy’, Journal of Financial Economics, 81(3): 563-594.

Hanlon, M. \& Slemrod, J. 2009. 'What does tax aggressiveness signal? Evidence from stock price reactions to news about tax shelter involvement', Journal of Public Economics, 93: 126-141.

Kim, J.B., Li, Y. \& Zhang, L. 2011. 'Corporate tax avoidance and stock price crash risk: Firm-level analysis', Journal of Financial Economics, 100: 639-662.

Lanis, R. \& Richardson, G. 2011. 'The effect of board of director composition on corporate tax aggressiveness', Journal of Accounting and Public Policy, 30: 50-70.

Leuz, C. \& Verrecchia, R.E. 2004. "Firms" capital allocation choices, information quality, and the cost of capital, Working Paper, University of Pennsylvania.

Phillips, J.D. 2003. 'Corporate tax-planning effectiveness: the role of compensation-based incentives', The Accounting Review, 78(3): 847-874.

Pittman, J. \& Fortin, S. 2004. 'Auditor choice and the cost of debt capital for newly public firms', Journal of Accounting and Economics, 37: 113-136.

Plesko, G.A. 2004. 'Corporate tax avoidance and the properties of corporate earnings', National Tax Journal, 57(3): 729-737.

Rego, S.O. 2003. 'An examination of corporate tax shelter participants', The Accounting Review, 84(3): 969-999.

Sengupta, P. 1998. 'Corporate disclosure quality and the cost of debt', The Accounting Review, 73(4): 459-474.

Wilson, R.J. 2009. 'An examination of corporate tax shelter participants', The Accounting Review, 84(3): 969-999. 